\title{
Dynamic Parameterization to Simulate DIN Export Due to Gypsy Moth Defoliation
}

\author{
Ping Wang ${ }^{1}$, Lewis C. Linker ${ }^{2}$, and Keith N. Eshleman ${ }^{3}$ \\ ${ }^{1}$ University of Maryland Center for Environmental Science, Chesapeake Bay Program \\ 410 Severn Avenue, Annapolis, MD 21403, USA \\ pwang@chesapeakebay. net \\ ${ }^{2}$ US Environmental Protection Agency/CBPO, 410 Severn Ave., Suite 109. \\ Annapolis, MD 21403, USA \\ linker.lewis@epa.gov \\ ${ }^{3}$ University of Maryland Center for Environmental Science, Appalachian Laboratory \\ 301 Broddock Road, Frostburg, MD 21532, USA \\ eshleman@al.umces.edu
}

\begin{abstract}
A module of dynamic parameterization is added into the HSPF watershed software for simulation of dissolved inorganic nitrogen (DIN) export from forest associated with gypsy moth defoliation. It simulates a changing ecosystem following the breakout of defoliation, such as increasing mineralization and nitrification rates and soil temperature, and decreasing interception of precipitation, plant nitrogen uptake rate and evapotranspiration. These parameter values vary with the stages of a defoliation event, such as the progressive period, the peak period, and the recovery period, the simulated DIN export from a multi-occurrence defoliation area in Shenandoah National Park in Virginia, USA, is comparable with the observed data.
\end{abstract}

\section{Introduction}

Forest is one of the important landuses in the Chesapeake Bay watershed (Fig. 1), covering about 60 percent of the area. The load of nitrogen (mass per unit area) is usually much lower from forest than from other landuses due to low nitrogen input, and high uptake and storage potential. However, increased dissolved inorganic nitrogen (DIN) export from mid-Appalachian forest following insect defoliation by the gypsy moth caterpillar (Lymantra dispar) has been observed at numerous sites $[1,2]$. Efforts have been made to simulate such conditions in computer models in order to improve watershed calibration and loading computations, with varying degrees of success $[3,4]$. However, these efforts are not successfully associated within the widely applied watershed models, such as HSPF (Hydrologic Simulation Program Fortran) [5]. The HSPF software is the primary tool to estimate nutrient load to the Chesapeake Bay, the largest estuary in the USA, from its watershed. The current Chesapeake Bay Watershed Model (CBWSM, which uses HSPF) does not consider nutrient processes involving gypsy moth defoliation [6]. It is desired for HSPF to have the capability in simulation of DIN export associated with gypsy moth defoliation, so that to provide more accurate information for nutrient management decisions. 
The implementation of a watershed model with gypsy moth defoliation requires understanding of physical, chemical, and biological processes associated with the defoliation, and a model structure capable of simulating these processes. Wang et al. [7] discussed the consequences of ecosystem changes after defoliation and the adjustment of related parameters in HSPF for the ecosystem simulation. They obtained elevated DIN export, and demonstrated a prospective of using HSPF to simulate gypsy moth defoliation. However, the parameter adjustments were confined in the parameter blocks of the HSPF input-deck. The HSPF allows these parameters to vary among months but with the same values in every year for that months, and cannot specify a value in the middle of a month. Therefore, the simulated daily DIN export did not match well with the observed. The timing of outbreak, and the duration and intensity of gypsy moth defoliation are different in different occurrences. Therefore, it is important to have a dynamic parameterization for different stages in a defoliation event and for different occurrences of defoliation. Although the "Special Action" of the HSPF allows dynamic change in many parameters, its restrictions do not fully meet our requirements. We setup a module to change parameter values dynamically. This paper describes how we setup the module of dynamic parameterization in HSPF, and presents the simulated DIN export from a multi-occurrence defoliation area over a few years.

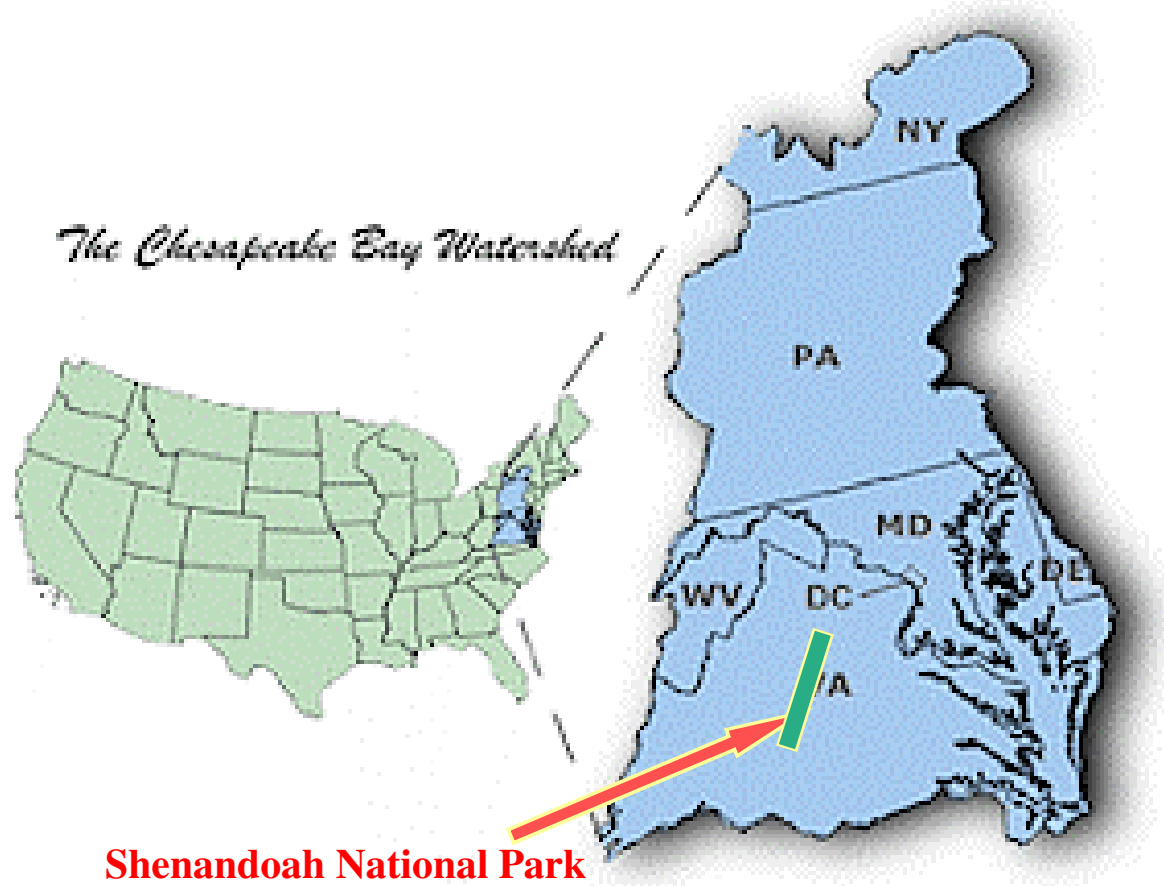

Fig. 1. Location of Shenadoah National Park and Chesapeake Bay watershed, USA 


\section{Method}

HSPF version 11 is the base code for the model simulation. A dynamic parameterization module was added, so that parameter values can change with the changing ecosystem in different stages of a defoliation event. Note: the original HSPF version 11 code yielded lower DIN exports under higher flows when using the Michaelis-Menton saturation kinetics for plant nitrogen uptake [8]. Prior to adding the dynamic module, the associated code was corrected to yield a positive relationship between DIN export and flow in high flow conditions [9]. Most of the parameters used in this study are based on the CBWSM Phase 4.3 calibration for nondefoliation forest in the above-fall-line of the Piegmont area of the Rappahannack River basin, which is referred to as the "base condition" in the following text.

Defoliation could result in a variety of effects on the forest [10], such as 1) reduction in transpiration rate, 2) decrease in uptake of nutrient by plants, 3) higher soil temperature due to increased radiant energy flux to forest floor, and 4) alterations in microbiological activity. In the simulation of gypsy moth defoliation, the above changes in the ecosystem are considered. While other external conditions (i.e., precipitation, other meteorological conditions, and atmospheric nitrogen deposition) are set the same as in the base calibration. The dynamic parameterization module allows user to specify the following information related with a defoliation even: the beginning, peak and ending date of defoliation, percent coverage of defoliation area versus the forested area, intensity of defoliation (i.e., percentage of trees is defoliated in the defoliation area), parameter values such as plant uptake rate, mineralization and nitrification rates, evapo-transpiration rate, intercept of precipitation, and soil temperature factors in the peak and normal conditions. The lag time between the maximum change of some parameter values and the peak defoliation can be set by the user for ease of calibration, although it is not required.

The module converts the information to daily parameter values that vary with the stage of defoliation. During the recovery of the forest, the parameter values change back gradually to the normal condition. The model can also handle multioccurrence of defoliation events. With the module, the HSPF updates these parameters in the simulation run. The module is, in fact, a bridge between the HSPF simulation and the info of dynamic changes in parameters associated with defoliation stages. The defoliation events in this study are referred to a forested watershed, Piney River watershed of Shenandoah National Park (Fig. 1), during the period 1987-1993. The area of mapped defoliation is $3.8 \%, 32.3 \%, 34.0 \%, 15.2 \%$, $0.0 \%, 14.2 \%$ and $0.0 \%$ in $1987-1993$, respectively. The intensity of defoliation is set at $50 \%$, i.e., moderate heavy.

\section{Result}

With the above setting of parameters for gypsy moth defoliation, high DIN export was yielded (Fig. 2). 


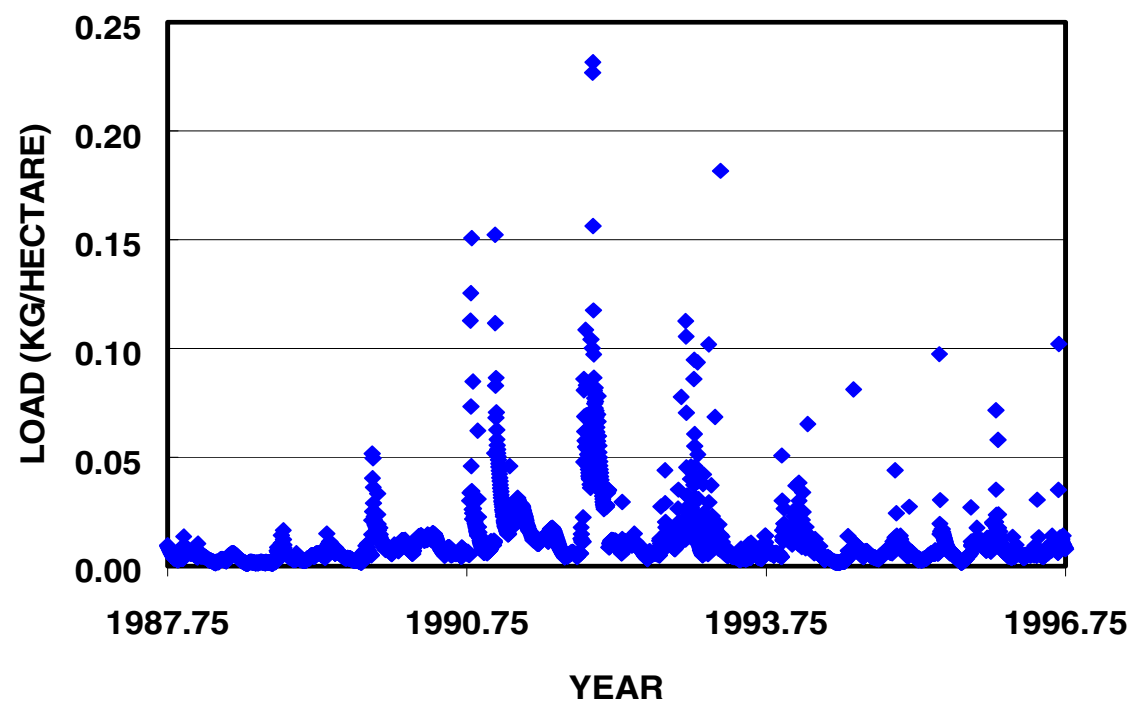

Fig. 2. Simulated DIN load from Piney River watershed in Shenandoah National Park using HSPF with a dynamic parameterization module

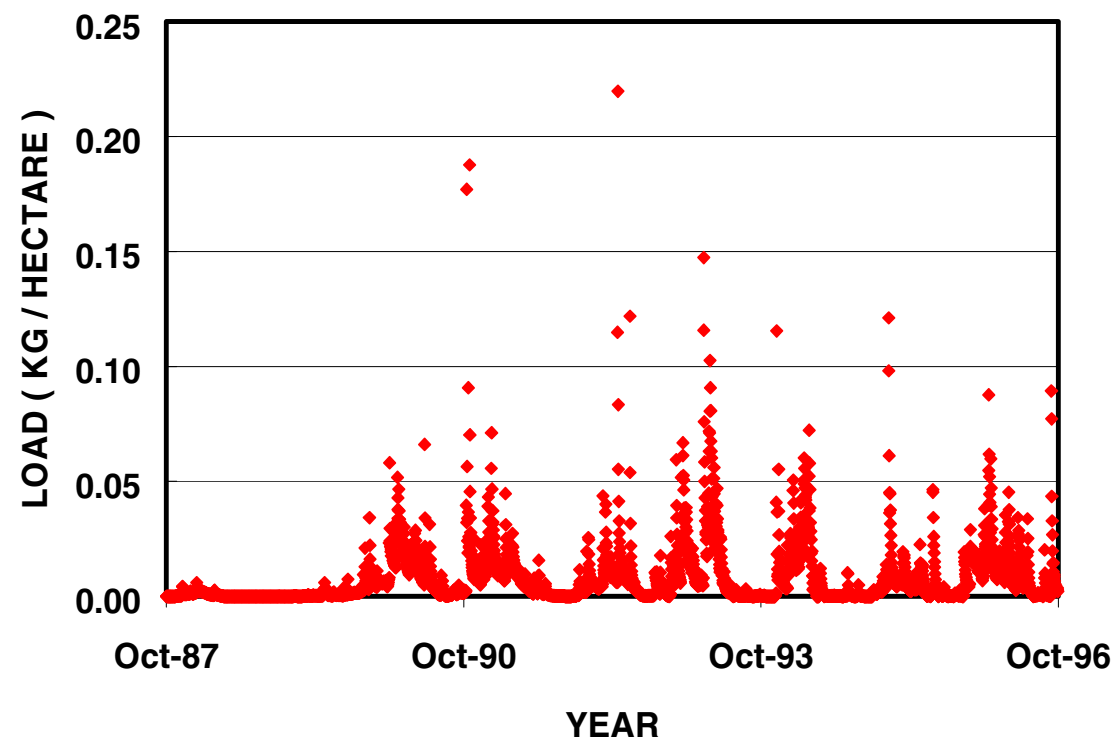

Fig. 3. Observed DIN loads from Piney River watershed in Shenandoah National Park, which undergone gypsy moth defoliation 
The pattern of the simulated DIN export (Fig. 2) is similar to that observed from the Piney River watershed (Fig. 3). The Piney River watershed is forested. Defoliation broke out in 1987 and the consecutive years, while elevated DIN export did not occur until late 1989, showing about 2-3 years of lag time between defoliation and elevate DIN export. This simulation run is a preliminary one, without an intensive calibration. In the model, the defoliation-related parameters are set dynamically for the simulated area, but may not be set optimally. Moreover, other non-defoliation related parameters, such as soil conditions, slope of land, size of forested area, average elevation, etc, are based on model segment 230 of CBWSM, which may not represent the simulated area correctly.

Flow is a primary force of DIN export. Hydrology is an important factor controlling the amount and timing of peak nitrogen export after defoliation, and the lag time between defoliation breakout and elevated DIN exports [7]. Figure 4 is the simulated flow.

Without considering defoliation, the simulated DIN export would be low, as shown in Fig. 5. Defoliation causes an elevated DIN export (Figs. 2 and 3).

This work shows that the DIN export associated with a real defoliation case can be simulated. It demonstrates that the HSPF is capable of simulating the conditions of gypsy moth defoliation with the help of a dynamic parameterization module.

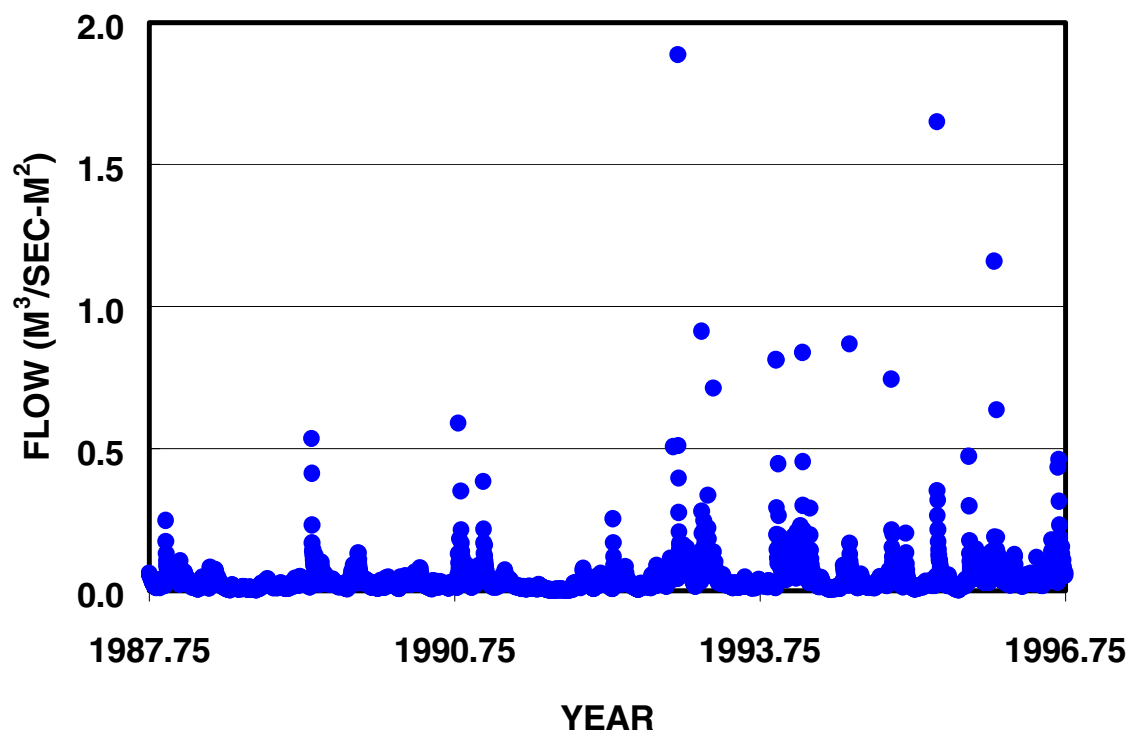

Fig. 4. Simulated edge of stream flow from Piney River watershed 


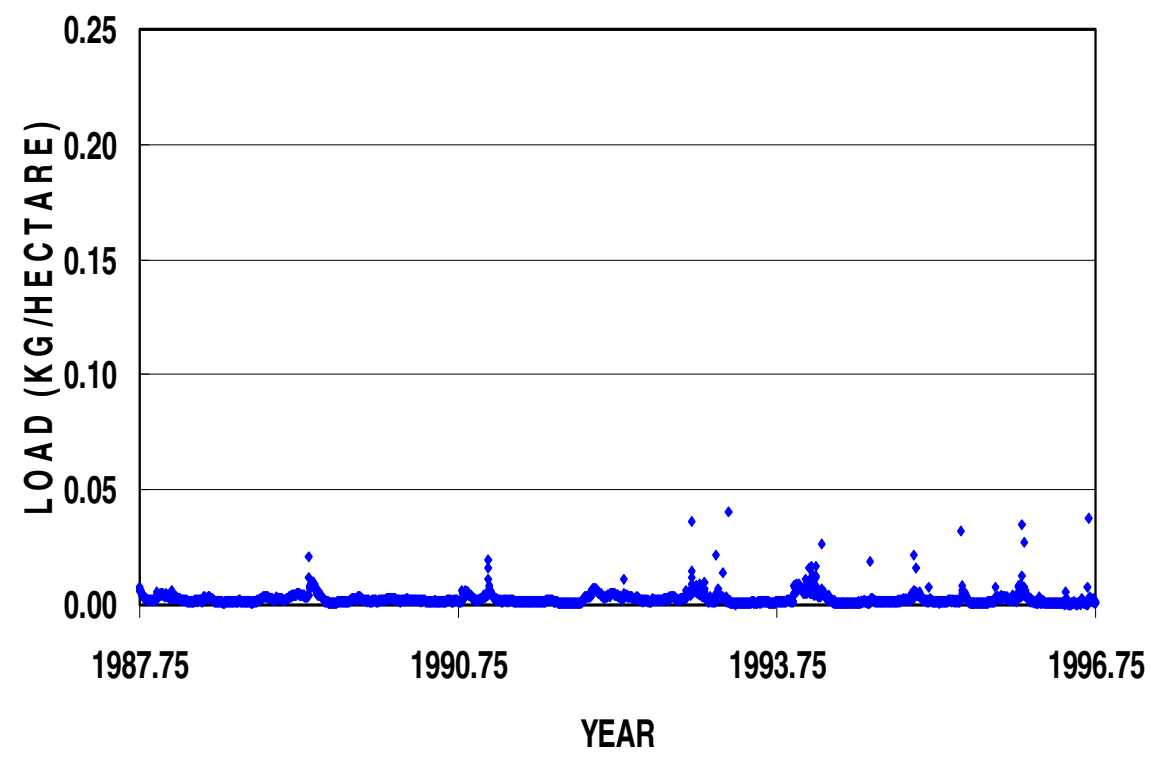

Fig. 5. Imulated DIN loads from forest of Segment 230 under the base calibration (i.e., without simulating defoliation)

\section{Discussion}

\subsection{Transformation of Organic Nitrogen to Inorganic Nitrogen}

The products of insect defoliation, such as insect biomass, frass, and litters, are important sources of organic nitrogen, and cause, through mineralization and nitrification, an increase in inorganic nitrogen availability [11][12]. The model simulates these sources as organic nitrogen and ammonia in the soil surface layer. These nitrogen constituents on the surface layer further transforms throughout the simulation period. Higher mineralization and nitrification rates after defoliation cause DIN more availability and higher export [7]. The mineralization rates of organic nitrogen and nitrification rates in the top soil layer are set as high as 10 times of the base calibration setting for a severe ecosystem change. The module allows a specification of lag time between the peak defoliation and the peak of tortured ecosystem. The rates and lag time can be adjusted through model calibration.

\subsection{Plant Uptake}

In the CBWSM, plant uptake rate (U)for forest is simulated with the MichaelisMenten saturation kinetics: 


$$
\mathrm{U}=\mathrm{Um} *(\mathrm{C} /(\mathrm{Ks}+\mathrm{C})
$$

where, Um is the maximum plant uptake rate, $\mathrm{C}$ is the concentration in soil, $\mathrm{Ks}$ is the half saturation constant. The Ks of nitrate and ammonia are usually referred to former work or the literature [12] and finalized by model calibration. Um is dependent on forest conditions. Under constant $\mathrm{Ks}$ and a specific $\mathrm{C}$, higher $\mathrm{Um}$ yields higher $\mathrm{U}$. In the CBWSM, Um is specified monthly, with higher in the summer and lower in the winter, and differs among soil layers. Plant uptake decreases significantly after defoliation (Bormann and Likens, 1979), which is one of the major cause of elevate DIN export after defoliation [7]. Correct simulating plant uptake is important in moderating nitrogen export from defoliated areas [13]. In gypsy moth defoliation model, the Um for a soil layer is suggested to be set at the lowest month rate of the base calibration in the temperate forest.

\subsection{Evapotranspiration (ET)}

In the CBWSM, evapotranspiration is determined by various factors, such as meteorological, soil, and vegetation conditions. The potential evapotranpiration (i.e., demand) is determined by meteorological conditions. The sources for evapotranspiration are, according to moisture availability for the demand, from the storage or outflow of soil layers. The loss of leaves by gypsy moth defoliation could cause significant reduction in transpiration of moisture taken by roots from the lower zone. This can be simulated through adjusting the lower zone evapotranspiration parameter, LZET. Reduction in LZET after defoliation could cause higher discharge and increase DIN export. Our assessment in Shenandoah National Park suggested that setting LZET at about a half of the base calibration value be appropriate in peak defoliation.

\subsection{Soil Temperature}

In the CBWSM, surface soil temperature is estimated by regression from empirical air and soil temperatures:

$$
\mathrm{Ts}=\mathrm{Y}+\mathrm{S} * \mathrm{Ta}
$$

where, Ts = surface layer temperature (degrees $\mathrm{C}), \mathrm{Y}=\mathrm{y}$-intercept of regression, $\mathrm{S}$ $==$ slope of the regression, and $\mathrm{Ta}=$ air temperature $($ degrees $\mathrm{C})$. The regression coefficients vary with months. The monthly y-intercept ranges from 2 to $16 \mathrm{de}$ grees $\mathrm{C}$ from winter to summer in the base calibration. In the gypsy moth defoliation simulation, the $y$-intercepts range from 5 to 25 degrees $C$ from winter to summer, while the slope is set the same as the base calibration. The elevated soil temperature in the simulation causes less organic nitrogen but slightly more DIN export [7]. This may be due to elevated soil temperature that promotes mineralization of organic nitrogen to DIN and subsequent nitrification. On the other hand, elevated soil temperature may also increase the evaporation rate, causing less flow and less 
DIN export. The overall effect of elevated soil temperature appears to cause lower organic nitrogen (OrN) for a long period, higher DIN in the earlier period following defoliation, but less DIN in later period due to depletion of organic nitrogen in the soil storage [7].

\subsection{Interception of Precipitation}

In the CBWSM, interception is specified monthly, with highest values in the summer and lowest values in the winter. In modeling gypsy moth defoliation, the interception values were set as the January value in the base calibration to simulate the decrease of interception capacity of tree after defoliation. A decrease of interception after defoliation causes more water to infiltrate and slightly higher DIN exports based on a 10year average [7]

Wang et al. [7] noticed that in some high flow days after the defoliation DIN export is slightly less than that by assuming a higher interception as the base calibration setting. This may be due to the fact that on high precipitation days the soil moisture storage meets ET demand in both defoliation and non-defoliation cases. In the defoliation case, less interception has more remaining ET demand for the lower layers and has lower ratio in groundwater/surface runoff, causing a relatively lower DIN/OrN ratio in export, because DIN export is related more with interflow or groundwater flow, and OrN export is related more with surface flow. Moreover, a high export of OrN in the early period of gypsy moth defoliation may allow less conversion of OrN to DIN in later days [7]. Nevertheless, in a 10-year average, both DIN and OrN exports are higher under the lower interception condition.

\section{Conclusion}

The above work shows that dynamic parameterization enables the HPSF watershed software to simulate gypsy moth defoliation. Under the defoliation conditions, insect biomass, frass, and leaf debris are important nitrogen sources for the forest soil. The changes in the forest ecosystem following defoliation play important roles in controlling rates of nitrogen export. The decrease of plant uptake is an important factor. The increase in biological activities causes higher availability of DIN in soil layer, leading to higher nitrogen export. Decrease in transpiration and interception increases flow and nitrogen export. The increase in soil temperature can increase evaporation rates and decrease flow and DIN export. However, the increase in soil temperature increases ammonification and nitrification rates, increasing DIN export. Hydrology pattern controls the amount and timing of nitrogen export. The availability of nitrogen in soil and hydrological forcing determine the lag time of peak DIN export after defoliation. The effect of gypsy moth defoliation can affect nitrogen export for several years. 


\section{References}

1. Webb, J.R., Cosby, B.J., Deveney, F.A., Eshleman, K.N., Galloway, J.N.: Change in the acid-base status of an Appalachian mountain catchment following forest defoliation by the gypsy moth. Water Air Soil Pollut., (1995) 85, 535-540

2. Eshleman, K.N., Morgan R.P., Webb J.R, Deviney, F.A., Galloway, J.N.: Temporal patterns of nitrogen leakage from mid-Appalachian forested watersheds: Role of insect defoliation, Water Resour. Res. (1998) 34, 2005-2016

3. Castro, M.S., Eshleman, K.N., Morgan, R.P., Seagle, S.W., Gardner, R.H., Pitelka, L.F.: Nitrogen dynamics in forested watersheds of the Chesapeake Bay, Scientific \& Technical Advisory Committee Publication 97-3, Chesapeake Bay Program, Annapolis, Maryland, USA. (1997)

4. Eshleman, K.N.: A linear model of the effects of disturbance on dissolved nitrogen leakage from forested watersheds, Water Resour. Res. (2000) 36, 3325-3335

5. Bicknell1, B.R., Imhoff1, J.C., Kittle, J.L, Donigian, A.D., Johanson, R.C.: Hydrological Simulation Program - FORTRAN, User's manual for version 11, U.S. Environmental Protection Agency, National Exposure Research Laboratory, Athens, Ga., EPA/600/R97/080, (1997) p755

6. Linker, C.L, Shenk, W.G., Wang, P.,Storrick, J.M.: Chesapeake Bay Watershed Model Application \& Calculation of Nutrient \& Sediment Loading, Appendix B, EPA903-R98-003, CBP/TRS 196/98 (1998)

7. Wang, P., Linker, L.C., Shenk, G.W., Eshleman, K.N.: Computer model of nitrogen export from disturbed forest by Gypsy moth defoliation. Proceeding of 5th International Conference on Diffuse/Nonpoint Polutionand Watershed Management, Milwaukee, WI, USA (2001) Sec.24, 7-15

8. Wang, P., Linker, L.C.: Effect of moisture on nitrogen export: comparison of two plant uptake saturation kinetics models. EOS Trans. AGU, 82(20), Spring Meet. Suppl., Abstract H41B-01, (2001) Boston, USA

9. Wang, P., Linker L.C.: Improvement of HSPF watershed model in plant uptake and DIN export from forest. EOS Trans. AGU, Fall Meet. Suppl., Abstract H12H-12, (2001) San Francisco, USA

10. Bormann, F.H., Likens, G.E.: Pattern and process in a forested ecosystem, SpringerVerlag, NY (1979) pp 253

11. Seastedt, T.R., Crossley, D.A.: The influence of arthropods on ecosystem. BioScience, (1984) 34, 157-161

12. Bowie, G.L, Mills, W.B., Porcella, D.B., Camplbell, C.L., Pagenkopf, J.R., Rupp, G.L., Johnson, K.M., Chan, P.W.H., Gherini, S.A., Chamberlin, C.E.: Rates, constants, and kinetics formulations in surface water quality modeling, NERL, US Environmental Protection Agency, Athens, GA, (1985) EPA/600/3-85/040, pp. 456

13. Swank, W.T.: Stream chemistry responses to disturbance, in: Forest Hydrology and Ecology at Coweeta, Swang W.T. and Croseley D.A. (ed), Springer-Verlag, New York, (1988) 237-271 